Bisset, K. A. (1955). J. gen. Microbiol. 12, 325-329

\title{
The Value of Cytological Studies in Elucidating Natural Relationships among Bacteria
}

\author{
By K. A. BISSET \\ Bacteriology Department, University of Birmingham
}

The nature of the ancestral bacterium is the fundamental problem in any evolutionary system, and this is a point upon which cytological evidence can be of considerable assistance. The classification of Bergey's Manual (1948) ignores this question almost completely, and confines itself to the suggestion that bacteria and blue-green algae are closely related. En passant, it may be remarked that the blue-green algae are perhaps the sole group in which no immediate relationship with the bacteria can be found because, alone of all living creatures, they show no evidence of ever having possessed flagella.

The evolutionary scheme of Kluyer \& van Niel (1936) commences with the assumption that the cocci are the ancestral group, because they alone have 'retained the primitive morphology'. It is, of course, tempting to believe that an apparently simple, spherical form is primitive, but a very small acquaintance with the cytology of cocci renders it apparent that their ostensible simplicity of form is exceedingly deceptive, and that they frequently possess a complex, septate structure, suggesting a relationship with the more highly evolved, septate Gram-positive bacilli. There are other serious objections to the scheme of Kluyver \& van Niel, notably that it requires an independent, multiple origin for flagella, endospores and Gram-positivity, and that the relationship of the 'primitive' coccus to other forms of life is entirely obscure.

In order to elucidate the problem of the ancestral bacterium from the cytological viewpoint, it is necessary to consider what are the cytological characteristics of bacteria as a group. Obviously, not all bacteria possess all, even of the most typical of these, in their most typical form, but there exist certain peculiarities which distinguish bacteria from other micro-organisms, and those forms in which one or other of these is absent are usually found to be quite closely related to others in which they are clearly recognisable.

The vegetative nucleus of bacteria is in the form of paired rodlets, dividing reductionally, and lying at right angles to the long axis of the cell. The resting nucleus is vesicular with an eccentric granule (cf. Bisset, 1950a). The flagella are monofibrillar. Divisions between adjacent cells contain an element of the cell-wall proper; the wall itself is slightly spiral (Pijper, 1946). There are, in addition, certain peculiarities of cytogenetic behaviour which are beyond the scope of this discussion.

The nature of their septation and the possession of flagella serve unequivocally to distinguish bacteria from blue-green algae, which bear a superficial resemblance to filamentous bacteria. Similarly, the resemblance of Streptomyces 
spp. to the asexual phase of certain ascomycetes, with which they have been compared, does not extend their nuclear structures, which are typically bacterial (Klieneberger-Nobel, 1947). In addition, an entire series of forms connects the 'higher bacteria' with their lower relatives.

If, therefore, bacteria are neither ascended from blue-green algae nor descended from moulds, much less arisen de novo from a simple, spherical cell, it is necessary to examine their internal relationships in order to discover a clue to their external derivation, and hence to the direction in which they may have evolved.

The most important clue in the list of characters given above is the observation that the clear-cut distinction formerly drawn between spiral and rodshaped bacteria for taxonomic purposes is not justifiable. The great majority of bacteria are, in fact, more or less spiral rods. Such exceptions as cocci or branched filaments have obvious affinities with more typical genera.

There is thus a complete series of forms between the markedly spiral, aquatic bacteria with polar flagella, and the much less spiral rods, common in soil but rarely and apparently accidentally found in water, which are either devoid of flagella or have a very large number arranged peritrichously. Although the latter are often described as actively motile, this usually means that they exhibit the power of swarming over a moist, solid surface, or in a viscous medium. A vibrio with a single polar flagellum swims much more efficiently than, for example, Proteus.

It thus appears highly probable that peritrichous flagellation and complete loss of flagella are alike adaptations of a fundamentally aquatic organism to a terrestrial environment. The alternative explanation, that the terrestrial bacteria have colonized the water, and evolved spirillar types via pseudomonads from bacilli, postulates a separate origin for bacterial flagella, and runs contrary to all experience in other groups of organisms. The return of a terrestrial form, once evolved, to an aquatic environment may occur in any group, and there is evidence of it also in bacteria, but the main trend is from aquatic to terrestrial in every case.

The series of intermediate forms between a spirillum and a bacillus is so obvious that the scheme of Kluyver \& van Niel also shows exactly this relationship, but attempts to derive the two ends of this chain independently from the 'ancestral' coccus, by suggesting that Gram-negative bacteria and pseudomonads are each more closely related to staphylococci than to one another. Even the most general acquaintance with bacterial morphology would render this proposition unattractive. The similar morphological series between the more and the less complex branched Gram-positive bacteria is also apparent, although their exact relationship with the Gram-positive spirilla is obscure.

The second phase in the process of evolution away from an aquatic environment usually consists in an exploitation of the potentialities of the atmosphere as a distributive agent, and this process can be observed in bacteria. Such obvious examples as the aerial hyphae and conidia of streptomyces hardly require emphasis, but a parallel mechanism is found in the stalked fruiting 
bodies of the higher myxobacteria, the vegetative swarms of which are capable of a crawling motion on solid surfaces. Further types of adaptation to aerial distribution are found among the septate Gram-positive bacilli and their relatives. Perhaps the most remarkable is the endospore, that uniquely resistant stage in the life cycle of the Bacillaceae (Bisset, 1950b).

It is not suggested that all aquatic bacteria are necessarily primitive. A high degree of adaptive specialization to this environment is exhibited by the sessile caulobacteria and chlamydobacteria, but both retain typically primitive characters in the motile distributive stages, which may resemble pseudomonads, vibrios, or even spirilla, and which indicate that these groups are quite closely related to the main line of bacterial evolution (Bisset \& Grace, 1954).

In general, the possession of flagella must be considered a primitive character, and the flagellate bacteria, together with their nearer relatives which may have lost their flagella at a relatively late stage of evolution, compose the order Eubacteriales. This definition includes a variety of caulobacteria, chlamydobacteria and others, especially autotrophs, which were until recently excluded from this order. Within the Eubacteriales, the most important subdivision is between the septate Gram-positive and the unicellular Gramnegative forms. In the classification I have proposed (Bisset, 1952) these are accorded the status of suborders, Bacillineae and Bacteriineae respectively. The true caulobacteria and the flagellated true spirochaetes are also granted subordinal rank, but the spirilla, pseudomonads and chlamydobacteria are all included with the typical Gram-negative bacteria in the suborder Bacteriineae. The Bacillineae comprises the true cocci and the lactic acid bacteria with the sporing bacilli. This suborder, however, has marked affinities with the order Actinomycetales (not including the true streptomyces which in some quarters continue to be miscalled actinomyces). Like these they are septate and Gram-positive, and many of the genera are entirely non-motile, but they are distinct in that their septation and cell-division is symmetrical, and in that they do not form lateral buds or branches, whereas the members of the Actinomycetales are irregularly septate and bud or branch more or less freely. In such circumstances the allocation of the suborder Bacillineae to one order or the other can only be an arbitrary decision. Almost certainly its members have a close affinity with the ancestors of the Actinomycetales and Streptomycetales, but their frequent possession of flagella cannot be ignored.

To return to the question of the origin of the simpler branched bacteria, it has been indicated that the streptomyces and the sporing bacilli resemble one another closely in respect of their nuclear cytology, and it is not beyond the bounds of possibility that some at least of the Actinomycetales may be descended via a more complex, branched sporogenous form, perhaps a true streptomyces, from the Gram-positive eubacteria. Certainly the nuclear behaviour of the ostensibly simpler members of the order is less typically bacterial than that of the more complex; so far, at least, as can be discerned.

At the same time, it must be confessed that the Actinomycetales constitute 
the order in which the least confidence of a common phylogeny can be placed. As always, much more information is required before firm opinions can reasonably be expressed, but an example of the sort of degenerative process which may be anticipated, and upon which cytology almost alone can shed a little light, is given by the description by Prévot (1953) of a system of temporary branching and of the maturation of the resting cell in a member of the Fusiformis group, which Prévot believes to be related to the anaerobic actinomyces. The cytological detail bears an astonishing resemblance to portions of the cycle in Actinomyces bovis described quite independently by Morris (1951). It is exceedingly improbable that the complex cycle in A. bovis, culminating in what appears to be a vestigial remnant of a process once designed to produce an aerial spore, could have been evolved in such delicate, anaerobic parasites as are both $A$. bovis and Fusiformis, but it is more than likely that they represent stages in the degeneracy of such parasites from a free-living, freely sporing ancestor. And to this extent the theory that the simpler bacteria are degraded from mould-like forms may have its share of truth. Comparable examples of functional degeneracy accompanying the adoption of a parasitic mode of life are probably afforded by Clostridium spp., Bacillus polymyxa and Rhizobium spp., and almost certainly the apparent extreme simplicity of structure of such obligate parasites as Brucella, Pasteurella or Haemophilus spp. is not primitive (Bisset, 1952).

On the other hand, certain morphological types of bacteria, notably pseudomonads, are endowed with a degree of versatility which enables them to adopt almost any mode of life, without undergoing modification.

One of the most encouraging features of this application of more refined morphological principles to the study of bacterial systematics is that the modifications which it imposes upon existing systems are almost without exception simplifications. Definitions of groups are especially simplified. A second encouraging feature is the manner in which evidence from such sources as biochemistry or genetics can be fitted into the same framework. But most encouraging of all is the reasonable explanation which it offers for so many hitherto confusing and enigmatic observations in the biology of bacteria.

\section{REFERENCES}

Bergey's Manual of Determinative Bacteriology, (1948). 6th ed. Edited by Breed, R. S., Murray, E. G. D. \& Hitchens, A. P. London: Baillière, Tindall and Cox.

Bisset, K. A. (1950 $a$ ). The differentiation of certain genera of Bacteriaceae by the morphology of the microcyst stage. J. gen. Microbiol. 4, 414.

Bisset, K. A. (1950b). Evolution in bacteria and the significance of the bacterial spore. Nature, Lond. 166, 431.

Bisser, K. A. (1952). Bacteria. Edinburgh: Livingstone.

Bisset, K. A. \& Grace, J. B. (1954). Autotrophic micro-organisms. Symp. Soc. gen. Microbiol. 4, 28.

KLIENEBERGER-Nober, E. (1947). The life-cycle of sporing actinomyces as revealed by a study of their structure and septation. J. gen. Microbiol. 1, 22. 
KuuYver, A. J. \& van Niel, C. B. (1936). Prospects for a natural classification of bacteria. Zbl. Bakt. (Abt. 2), 94, 369.

Monris, E. O. (1951). The life-cycle of Actinomyces bovis. J. Hyg., Camb. 49, 46.

PiJper, A. (1946). Shape and motility of bacteria. J. Path. Bact. 58, 325.

Prévot, A. R. (1953). Morphologie, physiologie, pouvoir pathogène et Systématique des Actinomycetales anaerobies. VI Congr. int. Microbiol. Symposium on Actinomycetales, p. 40. 